\title{
Peningkatan Pengelolaan Keuangan UKM Keripik Pisang di Kabupaten Tulungagung Melalui Sistem Keuangan Berbasis Microsoft Acces
}

\author{
Arief Rizki Fadhillah" ${ }^{\# 1}$, Dadang Hermawan ${ }^{* 2}$ \\ \#Program Studi D3-Otomotif, Universitas Widyagama Malang \\ Jalan Borobudur No 35 - Kota Malang \\ ${ }^{1}$ arief.rizki.fewidyagama.ac.id \\ 2dadang@widyagama.ac.id
}

\begin{abstract}
Sistem pengelolaan keuangan berbasis komputer menjadi hal yang mendesak, sehingga dapat membantu para UKM dalam menjalankan usaha dengan pengelolaan keuangan yang mudah dan baik. Salah satunya adalah UKM Ramesta yang masih menggunakan sistem manajemen tradisional, sehingga belum memiliki sistem pengelolaan keuangan yang memenuhi standar sesuai kaidah akuntansi. Berdasarkan permasalahan yang dihadapi oleh UKM Ramesta maka perlu adanya pelatihan kepada mitra UKM tentang pengelolaan keuangan berbasis Berbasis Microsoft Acces menggunakan software Cashflow Simplebook. Tujuan dari kegiatan ini adalah UKM mengalami peningkatan kinerja dan daya saing usaha. Metode pelaksanaan dalam penyelesaian permasalahan pada mitra UKM Ramesta, antara lain : identifikasi masalah, solusi permasalahan, diskusi tim pelaksana dan mitra UKM Ramesta, pelatihan sistem pengelolaan keuangan UKM berbasis Microsoft Acces, evaluasi penggunaan software cashflow simplebook terhadap pengelolaan keuangan UKM. Kesimpulan dari kegiatan ini adalah peningkatkan kemampuan serta pengetahuan mitra UKM Ramesta dalam mengelola sistem keuangan, penggunaan aplikasi Cashflow Simplebook membantu UKM Ramesta dalam menyusun laporan keuangan yang lebih baik
\end{abstract}

Keywords - Cashflow Simplebook, Microsoft Acces, Sistem Keuangan, UKM

\section{Pendahuluan}

Pelaku Usaha Kecil Menengah (UKM) mengalami kesulitan apabila harus menggunakan pengelolaan keuangan sistematis yang sesuai dengan kaidah akuntansi dalam menjalankan usahanya. Hal ini dikarenakan kurangnya pengetahuan yang dimiliki oleh para pelaku Usaha Kecil Menengah (UKM) [1]. UKM akan mampu meningkatkan kinerja usaha dan daya saing jika pengelolaan keuangan dilakukan dengan baik serta tersusun secara sistematis berdasarkan kaidah akuntansi [2]. Pengelolan keuangan yang baik dapat dilihat berdasarkan laporan keuangan usaha yang disusun oleh para pelaku Usaha Kecil Menengah (UKM).

Laporan keuangan adalah hasil dari akhir proses akuntansi dan alat yang dapat digunakan untuk memberikan informasi keuangan suatu usaha kepada pihak internal maupun ekternal. Tujuannya adalah memberikan informasi tentang posisi keuangan (financial position), kinerja keuangan (financial performance) dan arus kas (cash flow) dari usaha yang dilakukan, sehingga akan dapat menyusun keputasan secara ekonomis dari penggunanya. Beberapa bagian laporan keuangan, antara lain : neraca (balance sheet), laporan rugi laba (income statement), laporan perubahan modal, dan laporan arus kas [3].

Saat ini Usaha Kecil Menengah masih banyak yang menerapkan sistem manajemen tradisional. Hal ini disebabkan oleh beberapa faktor, antara lain : (a) pengelolaan UKM mengunakan sistem perorangan (one man show) atau dikelola oleh satu keluarga dengan suatu tradisi pengelolaan usaha, (b) Model UKM adalah usaha yang sederhana dengan tidak membutuhkan bahan baku yang banyak, memiliki proses yang sederhana serta varian produksi yang tidak terlalu banyak, (c) pola permintaan konsumen yang relatif tidak banyak berubah, (d) alat bantu proses dan produksi yang sederhana dengan tidak menggunakan alat yang tergolong berteknologi tinggi [4].

Salah satu UKM yang menggunakan sistem manajemen tradisonal ini adalah UKM Ramesta yang berlokasi di daerah Dusun Pecuk Desa Pecuk Kecamatan Pakel Kabupaten Tulungagung. Produk yang dihasilkan UKM 
Ramesta adalah keripik pisang dengan kapasitas produksi sebesar $\pm 25-35 \mathrm{~kg}$ per hari. Dalam kegiatan proses produksi, UKM ini dibantu dengan 6 orang. Tingkat pendidikan pemilik dan tenaga kerja pada UKM keripik pisang ini adalah lulusan SMA/sederajat. Rata-rata tenaga kerja keripik pisang ini masih memiliki hubungan sanak keluarga. Dalam menjalankan usahanya, UKM ini tidak memiliki pencatatan keuangan yang sesuai standar dkarenakan hanya menggunakan catatan buku yang sangat sederhana.

Permasalahan yang dihadapi UKM Ramesta adalah sistem pengelolaan keuangan yang masih sangat sederhana. UKM Ramesta dalam mengelola keuangan belum memenuhi standar keuangan usaha yang sehat, hal ini dikarenakan keuangan hanya mencantumkan pesanan dan harga total dari pesanan. Keuangan dalam UKM belum menjelaskan atau mencatat belanja bahan, bayar tenaga kerja, dan laba.

Dalam meningkatkan kemampuan pengelolaan keuangan UKM Ramesta, maka perlu adanya sebuah inovasi yaitu memberikan pelatihan kepada mitra UKM tentang pengelolaan keuangan berbasis komputer dengan menggunakan Program Microsoft. Acces.

Microsoft Access merupakan salah satu perangkat lunak yang diperuntukkan untuk mengolah database di bawah sistem Windows. Dengan menggunakan Microsoft Access, seseorang dapat merancang, membuat, dan mengelola database dengan mudah dan cepat [5].

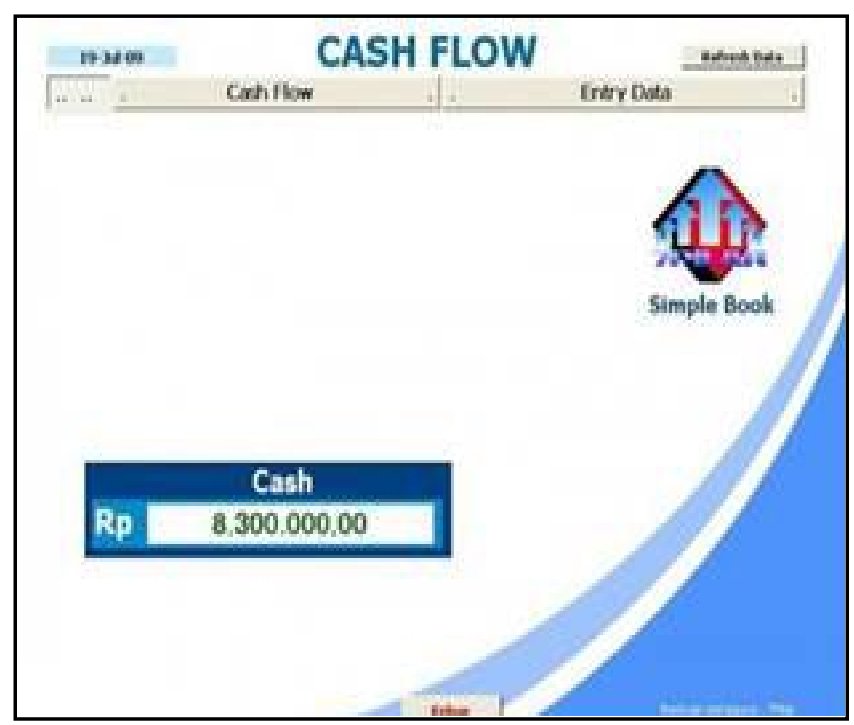

Gambar 1. Program CashFlow Simple Book [6]

Cashflow Simplebook adalah software yang dirancang dengan menggunakan program dasar Microsoft Acces. Software ini dapat digunakan oleh UKM dalam melakukan pembukuan keuangan usaha. Software ini sangat mudah dalam pengaplikasian, hemat waktu dan tepat guna. Manfaat dari Software adalah UKM akan dimudahkan mengevaluasi keuangan usaha dengan menggunakan software Cashflow Simplebook, terutama mengenai Alur Kas (Cash Flow) keuangan usaha [6]. Alur kas (Cash Flow) yang tercatat dalam Cashflow Simplebook, antara lain : modal, penjualan, pembelian, biaya operasional. Gambar 2 dibawah ini adalah contoh pembukuan yang terdapat Cashflow Simplebook.

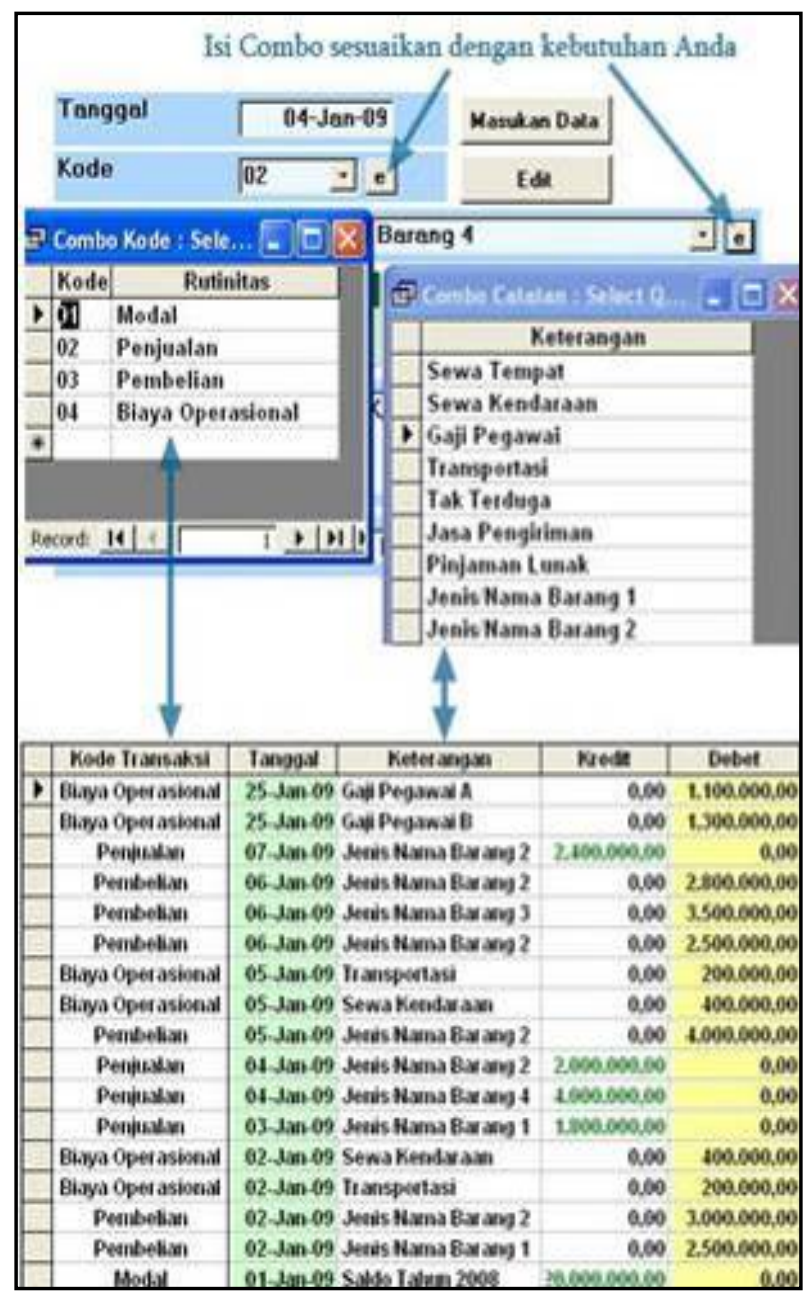

Gambar 2. Contoh Pembukuan Cashflow Simplebook [6]

Tujuan dari kegiatan ini adalah (a) meningkatkan kemampuan mitra UKM dalam mengelola sistem keuangan yang memiliki standar akuntansi melalui pelatihan sistem keuangan berbasis Microsoft Acces pada UKM Ramesta, dan (b) Mampu mengaplikasikan software cashflow simplebook dalam usaha yang dijalankan oleh UKM Ramesta.

Manfaat dari kegiatan ini adalah (a) UKM Ramesta memiliki pengetahuan dan kemampuan menjalankan sistem pengelolaan keuangan UKM menurut kaidah Akuntasi yang baik dan benar, (b) UKM Ramesta dimudahkan dalam mengontrol pengelolaan keuangan dengan menggunakan software cashflow simplebook, dan (c) Peningkatan usaha yang dijalankan oleh UKM Ramesta. 


\section{TARGET DAN LUARAN}

Dari permasalahan yang telah diidentifikasi oleh tim, maka solusi yang ditawarkan kepada mitra adalah peningkatan kemampuan UKM melalui pelatihan sistem pengelolaan keuangan berbasis Microsoft Acces. Target dan luaran yang diharapkan dari kegiatan ini adalah UKM dapat mengaplikasikan Sistem Keuangan Berbasis Microsoft Acces menggunakan software Cashflow Simplebook. Selain itu, UKM diharapkan mengalami peningkatan kinerja dan daya saing usaha.

\section{METODE PELAKSANAAN}

\section{A. Metode Pelaksanaan}

Metode pelaksanaan dalam penyelesaian permasalahan pada UKM Ramesta dapat dilihat dalam gambar 3. Kegiatan ini dilakukan dengan beberapa tahapan. Tahapan pertama, tim melakukan identifikasi masalah yang dihadapi oleh UKM. Berdasarkan hasil identifikasi masalah pada UKM Ramesta terdapat beberapa masalah, antara lain : pengelolaan usaha menggunakan manajemen tradisional, dan sistem pengelolaan keuangan belum mengikuti kaidah akuntansi yang baik dan benar .

Tahapan kedua, tim pelaksana memberikan solusi yang ditawarkan kepada UKM Ramesta dalam menyelesaikan masalah manajemen pengelolaan keuangan yaitu pelatihan sistem pengelolaan keuangan berbasis microsoft acces menggunakan software cashflow simplebook.

Tahapan ketiga, tim pelaksana melakukan diskusi dengan UKM Ramesta untuk menyepakati solusi penyelesaian masalah dan jadwal kegiatan pelatihan yang akan dilaksanakan Ramesta. Kegiatan pelatihan disepakati pada tanggal 15 Juli 2018.

Tahapan keempat, tim pelaksana dan pengelola UKM Ramesta melakukan pelatihan sistem pengelolaan keuangan UKM berbasis microsoft acces. Pelatihan ini dilberikan kepada pengelola UKM Ramesta untuk memberikan wawasan serta pengetahuan tentang sistem pengelolaan keuangan UKM berbasis Microsoft Acces dengan standar akuntasi yang baik dan benar, sehingga mitra UKM akan lebih baik dalam pengelolaan keuangan dan akan lebih meningkatkan permodalan mitra UKM dalam menjalankan usahanya. Adapun kegiatan dalam pelatihan ini, antara lain : pengisian kuisioner tingkat pemahaman materi oleh peserta pelatihan sebelum dan sesudah, pelatihan sistem keuangan berbasis Microsoft Acces, pengaplikasian sistem keuangan berbasis Microsoft Acces menggunakan software cashflow simplebook. Pelatihan ini dilaksanakan pada tanggal 15 Juli 2018 di UKM Ramesta yang berlokasi daerah Dusun Pecuk Desa Pecuk Kecamatan Pakel Kabupaten Tulungagung

Tahapan kelima, tim pelaksana melakukan evaluasi penggunaan software cashflow simplebook terhadap pengelolaan keuangan UKM Ramesta. Evaluasi ini bertujuan untuk melihat progress kemajuan dari pengaplikasian sistem keuangan berbasis Microsoft Acces menggunakan software cashflow simplebook terhadap pengelolaan keuangan UKM Ramesta.

Tahapan Keenam, tim pelaksana melakukan publikasi ilmiah dari hasil kegiatan pelatihan sistem pengelolaan keuangan UKM berbasis microsoft acces menggunakan software Cashflow Simplebook.

Tahapan terakhir adalah tim melakukan pelaporan kegiatan pelatihan sistem pengelolaan keuangan UKM berbasis microsoft acces menggunakan software Cashflow Simplebook.

\section{B. Diagram Alir Pelaksanaan}

Berdasarkan metode pelaksaan yang telah dijelaskan, maka diagram alir pelaksanaan kegiatan dapat dilihat pada gambar dibawah ini :

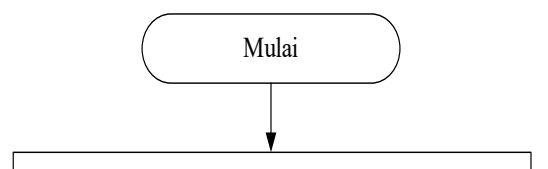

\section{Identifikasi Masalah:}

- Pengelolaan Usaha Menggunakan Manajemen Tradisional

- Sistem Pengelolaan Keuangan belum mengikuti kaidah akuntansi yang baik dan benar

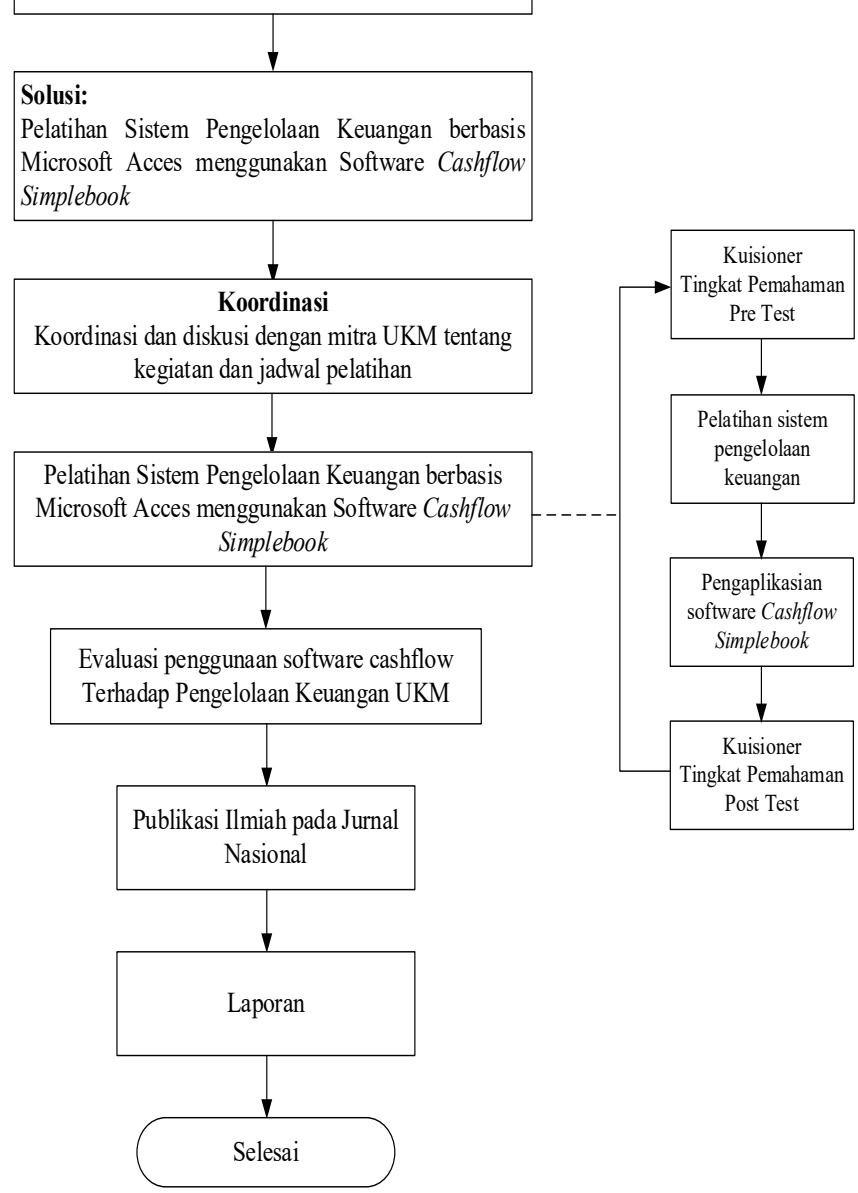

Gambar 3. Diagram Alir Pelaksanaan 


\section{HASIL DAN PEMBAHASAN}

A. Pelatihan Sistem Pengelolaan Keuangan Berbasis Microsoft Acces Menggunakan Software Cashflow Simplebook

Pelatihan dilaksanakan dengan melibatkan mitra UKM Ramesta yang beranggotakan 4 orang, antara lain : 1 orang pemilik dan 3 orang tenaga kerja. Pelatihan dilakukan dengan model seminar dan diskusi dengan durasi 120 menit. Materi Pelatihan yang dipaparkan oleh pemateri, antara lain :

1) Manajemen Keuangan

2) Sistem pengelolaan keuangan sesuai kaidah akuntansi

3) Dasar Microsoft Acces

4) Dasar-Dasar sistem pengelolaan keuangan berbasis Microsoft Acces dengan menggunakan software Cashflow Simplebook.

5) Praktik pengaplikasian software Cashflow Simplebook pada keuangan mitra UKM Ramesta.

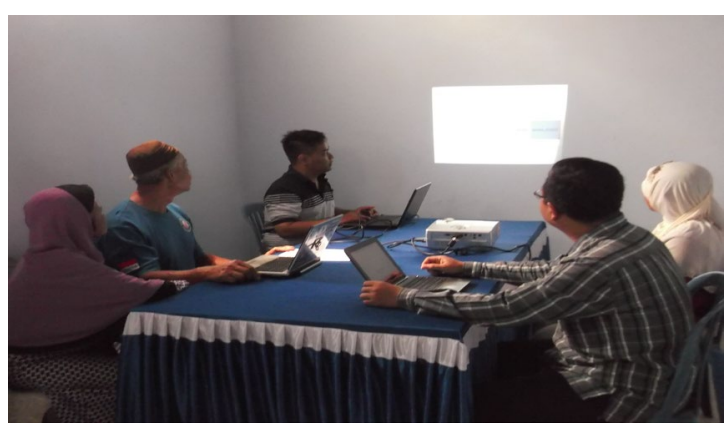

(a)

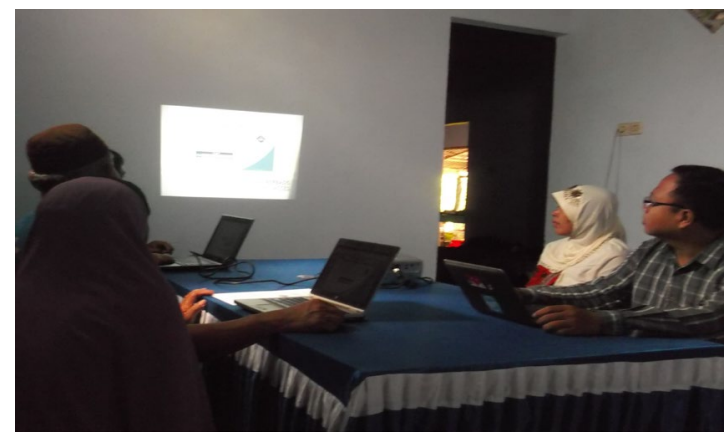

(b)

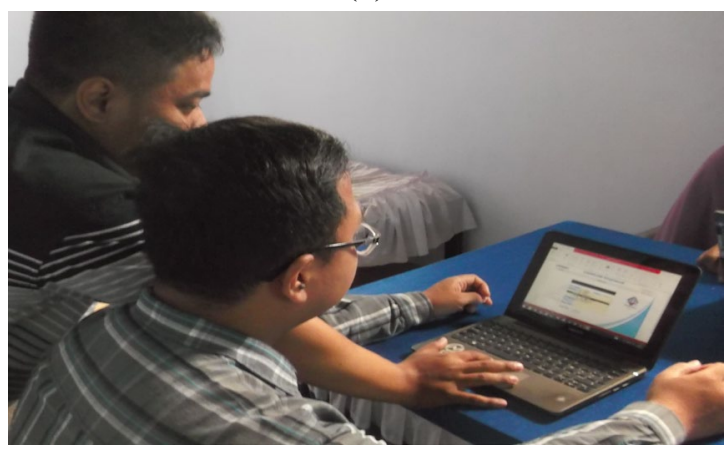

(c)

Gambar $3(a, b)$ pemaparan materi pelatihan, (c) praktik pengaplikasian software Cashflow Simplebook
Pada pelatihan ini para peserta sangat antusias dalam menerima beberapa materi yang disajikan oleh pemateri. Pelatihan diawali dengan pengisian kuisioner tingkat pemahaman materi yang akan disajikan oleh peserta pelatihan. Pengisian kuisioner bertujuan untuk mengevaluasi prosentase pengetahuan materi yang akan diberikan oleh pemateri, sehingga akan menjadi tolak ukur tingkat pemahaman materi oleh peserta bagi pemateri. Selanjutnya peserta pelatihan diberikan materi pelatihan sistem pengelolaan keuangan dengan format durasi waktu yaitu, 45 menit pemaparan materi, 45 menit praktik aplikasi software Cashflow Simplebook, dan 30 menit diskusi tanya jawab. Kegiatan pelatihan diakhiri dengan pengisian kuisioner tingkat pehaman materi pelatihan yang sama dengan kuisioner sebelumnya. Dari kuisioner tersebut, maka pemateri dapat mengevaluasi tingkat pemahaman materi peserta terhadap materi yang telah diberikan. Adapun model kuisioner dapat dilihat pada gambar 4 .

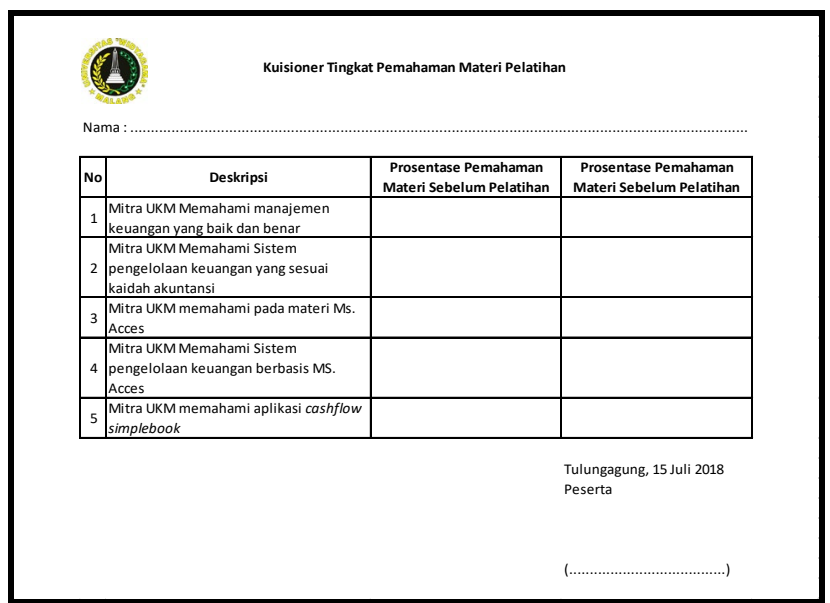

Gambar 4. Kuisioner Tingkat Pemahaman Materi Pelatihan

B. Tingkat Pemahaman Mitra UKM Terhadap Materi Pelatihan

Berdasarkan hasil pelatihan dan evaluasi tingkat pemahaman materi yang diberikan oleh pemateri kepada peserta, maka didapatkan grafik dibawah ini:

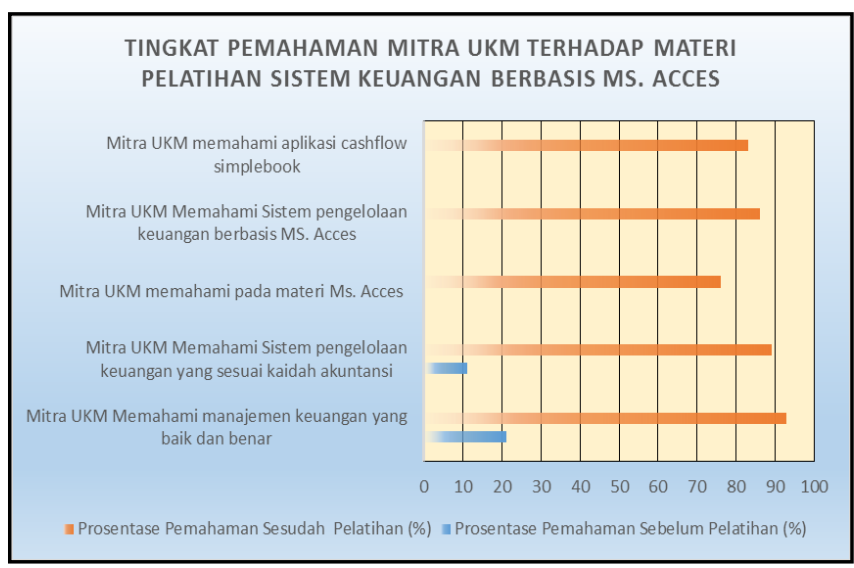

Gambar 5 Grafik Tingkat Pemahaman Materi Pelatihan 
Berdasarkan gambar 5 diatas dapat diketahui bahwa tingkat pemahaman mitra UKM sebelum dilakukan pelatihan terhadap materi sistem keuangan berbasis Microsoft Acces sangat rendah. Hal ini dapat dilihat dari jawaban 5 pertanyaan peserta dalam kuisioner, antara lain : mitra UKM memiliki pemahaman tentang manajemen keuangan yang baik dan benar sebesar $21 \%$, mitra UKM Memahami sistem pengelolaan keuangan yang sesuai kaidah akuntansi sebesar $11 \%$, dan peserta tidak memiliki pengetahuan tentang Microsoft Acces, sistem pengelolaan keuangan berbasis Microsoft Acces serta aplikasi cashflow simplebook yaitu sebesar $0 \%$. Dari hasil tersebut dapat terlihat bahwa kemampuan mitra UKM dalam mengelola sistem keuangan tidak memiliki pengetahuan yang memadai, sehingga kurang mampu dalam menjalankan usaha dengan sistem keuangan yang memenuhi standar.

Dalam meningkatkan kemampuan dan pengetahuan mitra UKM dalam mengelola sistem keuangan, maka tim pelaksana memberikan pelatihan sistem keuangan berbasis Microsoft Acces. Sistem keuangan ini dapat diplikasikan oleh UKM Ramesta sehingga akan membantu dalam pengelolaan keuangan yang dampaknya secara langsung pada kinerja usaha dari UKM.

Materi yang telah diberikan oleh pemateri dapat terlihat peningkatan yang signifikan pada pengetahuan dan pemahaman peserta dalam pengelolaan keuangan. Pada gambar 5 dapat dilihat bahwa mitra UKM memiliki pemahaman tentang manajemen keuangan yang baik dan benar sebesar 93\%, mitra UKM Memahami sistem pengelolaan keuanga yang sesuai kaidah akuntansi sebesar 89\%, Mitra UKM memahami pada materi Microsoft Acces sebesar $76 \%$, Mitra UKM Memahami Sistem pengelolaan keuangan berbasis Microsoft Acces sebesar 86\%, dan Mitra UKM memahami aplikasi cashflow simplebook sebesar 83\%. Peningkatan kemampuan ini dapat menjadi modal bagi mitra UKM dalam menjalankan usahanya dengan pengelolaan sistem keuangan yang lebih baik dan memiliki standar yang sesuai kaidah akuntansi.

\section{Evaluasi Penggunaan Software Cashflow Simplebook Terhadap Pengelolaan Keuangan UKM}

Evaluasi ini bertujuan untuk melihat kemajuan dari penggunaan software Cashflow Simplebook dalam pengelolaan keuangan UKM Ramesta. Dari hasil evaluasi yang dilakukan oleh tim pelaksana, bahwa pengelolaan keuangan yang dilakukan oleh UKM Ramesta telah memenuhi standar yang sesuai kaidah akuntansi. UKM Ramesta telah dapat membedakan aset, modal, belanja bahan baku, dan lain-lain. Selain itu, terjadi peningkatan kinerja usaha dengan penggunaan sistem keuangan dengan Cashflow Simplebook. UKM Ramesta memiliki komitmen dalam menjalankan sistem keuangan dengan Cashflow Simplebook secara continue.

\section{KESIMPULAN}

Berdasarkan hasil kegiatan yang telah dilaksanakan, maka dapat ditarik kesimpulan bahwa pelatihan sistem pengelolaan keuangan berbasis Microsoft Acces menggunakan Cashflow Simplebook dapat meningkatkan kemampuan serta pengetahuan mitra UKM Ramesta dalam mengelola sistem keuangan, serta penggunaan aplikasi Cashflow Simplebook membantu UKM Ramesta dalam menyusun laporan keuangan yang lebih baik dan transparan.

\section{UCAPAN TERIMA KASIH}

Penulis mengucapkan terima kasih kepada Universitas Widyagama Malang dan Lembaga Penelitian dan Pengabdian Masyrakat (LPPM) Universitas Widyagama Malang yang telah membiaya kegiatan ini melalui Program Pengabdian Masyarakat (PROPENMAS) Tahun Anggaran 2018.

\section{DAFTAR PUSTAKA}

[1] R. K. Hapsari, A. W. Azinar, and Sugiyanto, 2016, "Perancangan dan Pengembangan Pengelolaan Keuangan UMKM Berbasis Sistem Informasi," in Prosiding Seminar Nasional Teknologi Terapan (SNTT) SV UGM 2016, 2016, November, pp. 106209.

[2] Z.Puspitaningtyas, 2017,"Pembudayaan pengelolaan keuangan berbasis akuntansi bagi pelaku usaha kecil menengah," J. Akunt., vol. XXI, no. No. 3, pp. 361372.

[3] M. Alteza, 2012, "Manajemen Keuangan Praktis Bagi UMKM" .

[4] M. Hasyim and R. S. Subur,2014,"Pelatihan manajemen keuangan pada pelaku usaha toko kelontong dusun puluhan, desa banyusidi, pakis, magelang, jawa tengah," J. Inov. dan Kewirausahaan, vol. 3, no. 2, pp. 134-140.

[5] D. R. Taufani, 2009, Mengolah Data dengan Microsoft Office Acces 2007. Bandung: Microsoft User Group Indonesia.

[6] A. Nasution, "CASHFLOW Simplebook," 7 Pilar. [Online]. Available: http://simplebook.weebly.com/. [Accessed: 06-Dec-2016]. 